
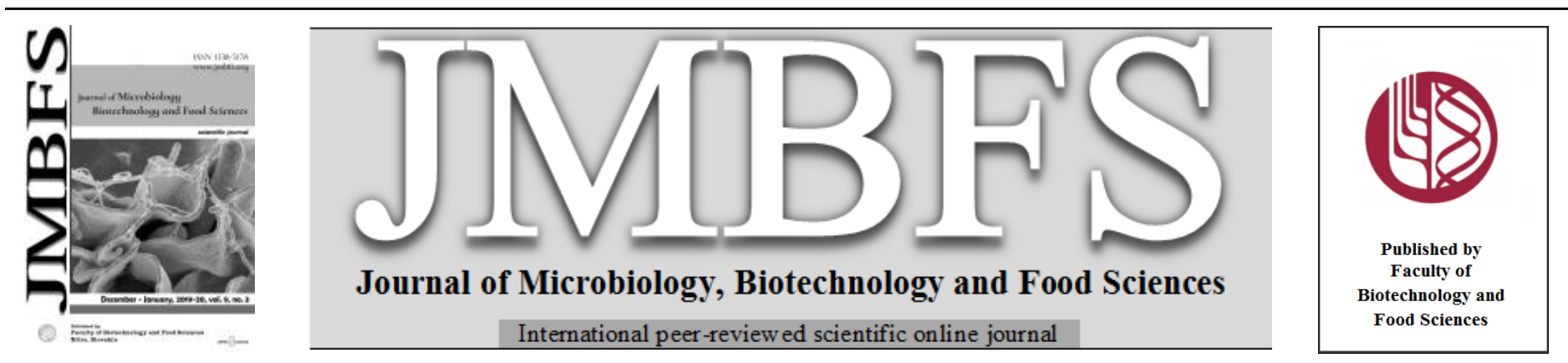

\title{
EFFICIENT LACTAMIDE SYNTHESIS BY FED-BATCH METHOD USING NITRILE HYDRATASE OF RHODOCOCCUS PYRIDINIVORANS NIT-36
}

\author{
Poonam Singh ${ }^{1}$, Ansu Kumari ${ }^{1}$, Chandrika Attri ${ }^{l}$, Amit Seth ${ }^{1,2 *}$ \\ Address(es): Dr. Amit Seth, \\ ${ }^{1}$ Faculty of Applied Sciences and Biotechnology, Shoolini University, Solan 173229, Himachal Pradesh (India). \\ ${ }^{2}$ Himalayan Centre of Excellence in Nanotechnology, Shoolini University, Solan (HP), Himachal Pradesh (India).
}

*Corresponding author: amitsethshimla@gmail.com

doi: $10.15414 / j m b f s .2019 / 20.9 .3 .567-572$

ARTICLE INFO

Received 7. 1. 2019

Revised 5. 6. 2019

Accepted 6. 6. 2019

Published 1. 12. 2019

Regular article

open $\mathcal{O}$ access

\begin{abstract}
Lactamide is used in the synthesis of lactic acid esters and as a solvent in many ecofriendly formulations. Till date lactamide synthesis was accomplished by employing chemical methods involving harsh reaction conditions while the enzyme-based approach ensures high purity lactamide synthesis under ambient environment without the intervention of acid byproducts using lactonitrile as substrate. Nitrile hydratase of Rhodococcus pyridinivorans NIT-36 was expressed by supplementing the growth medium with inducer i.e. lactamide. A 1.7-fold increase in enzyme activity was recorded by double feeding of the inducer. A further two-fold enhancement in enzymatic activity was achieved by the statistical optimization of process parameters for lactamide production by Response Surface Methodology. The substrate, lactonitrile inhibited the enzyme at higher concentrations, hence a fed-batch approach was adopted. The enzyme substrate ratio was standardized and the enzyme completely converted $15 \mathrm{mM}$ of lactonitrile to lactamide in 30 minutes using $2 \mathrm{mg} / \mathrm{ml}$ resting cells. The fed-batch was performed at $1 \mathrm{~L}$ scale and $100 \%$ biotransformation of $360 \mathrm{mM}$ of lactonitrile to lactamide was achieved at $45^{\circ} \mathrm{C}$ in 720 minutes. The catalytic productivity of $14.5 \mathrm{~g} / \mathrm{g} \mathrm{dcw} / \mathrm{h}$ for lactamide formation was finally recorded in the $1 \mathrm{~L}$ fed-batch reaction.
\end{abstract}

Keywords: Rhodococcus pyridinivorans NIT-36, Nitrile hydratase, Lactamide, biotransformation, fed-batch

\section{INTRODUCTION}

Lactamides are industrially important lactic amides which are used in the cosmetic industry as hair care products, as solvent in many pharmaceutical formulations. Lactamide derivatives are also responsible for lowering the toxicity of various compounds used in agrochemical formulations (Kanyon et al. 1949; Bell and Tovey, 2015). These compounds are used as solvents with the wide range of materials comprising herbicides, fungicides, acaricides, nematicides and insecticides. They are also used as plant growth regulators. The low toxicity of the solutions containing lactamides makes them suitable for skin creams, lotions, sun creams, personal hygiene products and pharmaceutical formulations, such as tablets, suppositories, inhalers, dermal creams and lotions (Krieken, 2013). Chemically lactamide is synthesized by hydrating lactonitrile in the presence of a chemical catalysts like manganese oxide (Tanaka et al. 1998). Unsaturated lactamides are prepared by heating an alkyl lactate, with an alkenyl amine (Kanyon et al. 1949). Lactamide synthesis has been accomplished previously by chemical methods only, nonetheless in this paper we are reporting enzymatic biotransformation of lactonitrile to lactamide.

Nitrile hydratase (NHase) catalyzes the breakdown of cyanide containing nitriles to corresponding amides. It had been reported from a wide variety of bacterial species (Pratush et al. 2010). The NHases are metalloenzymes encompassing either an iron (Fe-type NHase) or a cobalt (Co-type NHase) in the catalytic center. These enzymes have tremendous applicability as the biotransformation reactions of diverse nitriles to amide compounds is achievable under ambient conditions of temperature and $\mathrm{pH}$. These enzyme catalyzed biotransformations serve as an alternative to chemical hydrolysis of nitriles, which requires harsh conditions (with strong acids or bases at high temperatures) that may cause decomposition of vital functional groups of the molecule (Pratush et al. 2012). These problems could be overcome by the use of nitrile-hydrolysing enzymes in processes which operate in mild reaction conditions (buffered solution, low temperature and moderate $\mathrm{pH}$ ). Besides, the substrate lactonitrile can be obtained at roughly one-tenth of the cost of lactamide thus making the process economically viable. In this article we report enzyme mediated bench scale production of lactamide. In this study we report a fed-batch method for synthesis of lactamide from lactonitrile using resting cells of $R$. pyridinivorans NIT-36. This microrganism $R$. pyridinivorans NIT-36 was isolated in our lab from soil samples of hot water spring of Tattapani (District: Mandi, Himachal Pradesh). This strain was deposited in Microbial Type Culture Collection facility (MTCC) located at IMTECH Chandigarh with accession number MTCC 12617.

\section{MATERIALS AND METHODS}

\section{Chemicals}

Lactonitrile and lactamide were purchased from Sigma-Aldrich Corporation While other chemicals were of analytical grade and purchased from the standard commercial suppliers. Media ingredients were procured from HiMedia, Mumbai, India.

\section{Microorganism and culture conditions}

$R$. pyridinivorans NIT-36 was procured from our laboratory. This strain is deposited in Microbial Type Culture Collection with accession number MTCC 12617 and the 16S rDNA sequence of the strain has been deposited in the GenBank database under accession number KP055054. It was cultured as described previously (Singh et $\boldsymbol{a l}$. 2017) with one variation i.e inducer (lactamide). The $R$. pyridinivorans NIT-36 cells were suspended in $100 \mathrm{mM}$ of potassium phosphate buffer $(\mathrm{pH} 7.0)$ such that it contained $15 \mathrm{mg}$ of dry cell weight $(\mathrm{dcw} / \mathrm{ml})$ and these cells were used as source of NHase.

\section{Assay for NHase activity}

The NHase assay system contained (per milliliter of reaction mixture) potassium phosphate buffer ( $\mathrm{pH} 7.0), R$. pyridinivorans NIT-36 cells (1.5 mg dcw) and 15 $\mathrm{mM}$ of lactonitrile. The reaction was carried out at $45^{\circ} \mathrm{C}$ for 10 minutes and stopped by adding an equal volume of $0.1 \mathrm{~N} \mathrm{HCl}$. Lactonitrile has boiling temperature of $221^{\circ} \mathrm{C}$ where it decomposes so it can be ideally used for substrate by thermophilic isolates. The product lactamide is a white crystalline solid and has a melting temperature of $76^{\circ} \mathrm{C}$, hence the reaction temperature did not have an adverse effect on the reactants and products (Singh et al. 2017).

Analytical method 
The amount of lactamide formed was assayed by HPLC with Agilent 1200 series, Chem-station Software, 6.0 version, column dimension: Zorbax-Eclipse XDB$\mathrm{CN} ; 4.6 \times 150 \mathrm{~mm}, 3.5 \mu \mathrm{m}$ at a flow rate of $0.8 \mathrm{ml} / \mathrm{min}$. The solvent system used consisted of (a) $0.1 \% \mathrm{H}_{3} \mathrm{PO}_{4}$ and HPLC grade Water (v/v) and (b) $70 \% \mathrm{CH}_{3} \mathrm{CN}$ (acetonitrile) with $1 \mathrm{~mL}$ of $1.8 \mathrm{mM}$ ethanolamine and the gradient mode was reverse phase HPLC. The conversion was detected with DAD UV-VIS detector at $\lambda=225 \mathrm{~nm}$. This is a modified method based on HPLC detection of nicotinamide (Pratush et al. 2017). The retention time 17.9 minutes was observed for the production of lactamide. One unit of NHase activity was defined as the amount of enzyme, which converts one micromole of lactonotrile to lactamide per min under the assay conditions.

Effect of different types of inducers (nitriles and amides) on the NHase activity of Rhodococcus pyridinovorans NIT-36

Most of the NHases so far reported are inducible enzymes and are generally induced by the product of the reaction. To study the effect of inducers i.e. filter sterilized nitriles $(0.2 \% \mathrm{v} / \mathrm{v})$ acetonitrile, acrylonitrile, adiponitrile, benzonitrile, butyronitrile, propionitrile, valeronitrile and amides $(0.2 \% \mathrm{w} / \mathrm{v})$ acrylamide, butyramide, benzamide, lactamide was added in the production medium. The culture was incubated at $37^{\circ} \mathrm{C}$ for $24 \mathrm{~h}$

\section{Effect of inducer concentration on the NHase activity}

To study the effect of inducer concentration on the NHase activity of $R$. pyridinivorans NIT-36, different concentrations of lactamide (as it emerged as an efficient inducer for the production of lactamide) ranging from $0.1-1.0 \%(w / v)$ were used and NHase activity was assayed.

\section{Hyperinduction of NHase of Rhodococcus pyridinivorans NIT-36}

To enhance the NHase activity various sets of experiments were performed for $R$ pyridinivorans NIT-36. Growth and enzyme activity were monitored till $48 \mathrm{~h}$ Total four sets of different reactions were designed and two controls were used. In control 1 no inducer was added and in control 2, inducer $(0.1 \% \mathrm{w} / \mathrm{v})$ was added only once. The details of inducer feedings have been outlined in Table 2 Two control experiments were used, in control 1 , no inducer was added and cells attained stationary phase at $24 \mathrm{~h}$ with no enzyme activity while in control 2 , inducer $(0.2 \%)$ was added only once at $0 \mathrm{~h}$ and an increase in enzyme activity was observed till $24 \mathrm{~h}$. In the successive two experiments the inducer (lactamide) was added after every $12 \mathrm{~h}$ and cells were harvested after $48 \mathrm{~h}$. The induce concentration was varied with each successive addition which included both exponential increase as well as decrease in inducer concentration during multiple feedings. However, the enzyme activity displayed a decreasing trend which could be attributed to the higher accumulation of the inducer in the production medium and subsequent inhibitory effect on enzymatic activity. To prevent enhanced build-up of inducer in the production medium, multiple feedings were replaced with double feedings with a time lapse of $24 \mathrm{~h}$ (experiment 3 and 4) as indicated in Table 2 thus averting rapid accumulation of the inducer and preventing enzyme inhibition. In experiment 3 , the inducer concentration level was raised in the second feeding while in experiment 4 (Table 2) the inducer concentration was kept constant $(0.2 \% \mathrm{w} / \mathrm{v})$ for both the feedings. A 12 -hour gap was selected as a regular addition of inducer, because a shorter time interval would have had an inhibitory effect on NHase enzyme.

\section{Statistical optimization of reaction conditions by RSM for lactamide synthesis by whole cells of $R$. pyridinivorans NIT-36}

A factorial, central composite design for four independent variables with replicates at the center points used in this work. Based on the previously executed experiments, four different variables were chosen $\left[\mathrm{pH}(6-8)\right.$, temperature $\left(40^{\circ} \mathrm{C}-\right.$ $\left.50^{\circ} \mathrm{C}\right)$, substrate concentration $(10 \mathrm{mM}-20 \mathrm{mM})$, cell volume $\left.(50 \mu \mathrm{L}-150 \mu \mathrm{L})\right]$ which were supposed to have significant effect on lactamide production. These individuals were studied at three levels $(-1,0,+1)$ using RSM. The statistical analysis of the results was completed by using Design Expert version8 statistical software (Stat-Ease Inc, Minneapolis, MN). The growth and enzyme activity were analyzed using the analysis of variance (ANOVA) combined with the Fischer test to evaluate if a given term has a significant effect. The experiments were performed in triplicate and statistical analysis was done using RSM/ANOVA. The optimum levels of the variables were obtained by graphical and numerical analysis using Design Expert program (Table 3).

\section{Scaled-up production of lactamide using hyper induced resting cells and analysis of products}

The batch reactions were carried out at $45^{\circ} \mathrm{C}$ in $100 \mathrm{ml}$ reaction mixture for complete conversion of lactonitrile to lactamide using appropriate concentration of resting cells of $R$. pyridinivorans NIT-36 (2-8 $\mathrm{mg} \mathrm{dew} / \mathrm{ml}$ reaction mixture) The substrate concentration at $100 \mathrm{ml}$ scale was varied from $15 \mathrm{mM}$ to $30 \mathrm{mM}$. The time course for complete conversion was estimated and based on these results, a fed-batch method was designed at $1 \mathrm{~L}$ scale in a fermenter Bioage
(MM3010). The fed-batch reaction was performed in potassium phosphate buffer $(\mathrm{pH} 7.0)$ containing $2 \mathrm{mg}(\mathrm{dcw})$ resting cells $(100 \mathrm{ml})$ and $15 \mathrm{mM}$ substrate was added after every 30 minutes. The reaction was carried out for 12 h. The reaction mixture was centrifuged $\left(10000 \mathrm{rpm}\right.$ for 15 minutes at $\left.4{ }^{\circ} \mathrm{C}\right)$ to remove the cells. The supernatant was air dried and lactamide formation was confirmed by HPLC.

\section{RESULTS}

Effect of different types of inducers and inducer concentration on NHase activity

A number of amides have been previously synthesized by the usage of NHase enzyme, but a detailed investigation of process parameters for lactamide synthesis has not been attempted before. The NHase of $R$. pyridinivorans NIT-36 is an inducible enzyme and was able to metabolize lactonitrile only when lactamide was added as an inducer in the production medium. This organism also contains nitrilase and amidase enzymes (Kumari et al. 2016; Jyoti et al. 2017) In the present case lactamide was the most efficient inducer for lactonitrile biotransformation (Figure 1).

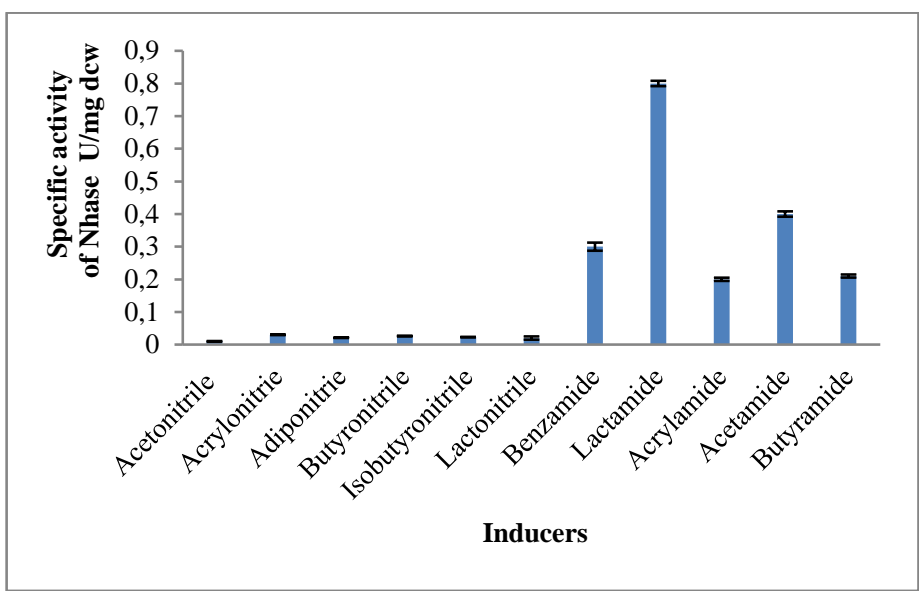

Figure 1 Effect of different inducers on NHase production by $R$. pyridinivoran NIT-36 for lactamide synthesis. The highest activity was recorded in presence of lactamide

Subsequently the concentration of inducer (lactamide) was varied $(0.1-1 \% \mathrm{w} / \mathrm{v})$ and at higher concentrations the inducer exhibited an inhibitory effect on lactonitrile degradation capacity of NHase enzyme (Table 1). The selective induction of NHase and non-activation of nitrilase and amidase was confirmed through HPLC and it was also ensured that no residual lactamide (inducer) was present before the start of enzymatic reaction. This was achieved by thorough washing of the cell pellet repeatedly in potassium phosphate buffer $(0.1 \mathrm{M}$; $\mathrm{pH}$ 7.0) so as to remove any traces of amide in the resting cell suspension. In single induction, $0.2 \%(\mathrm{w} / \mathrm{v})$ was found to be the best inducer for lactamide synthesis. Before initiating the bench scale production, enhanced production of NHase was attempted by involving multiple feedings of inducer (Table 2). This was deemed as a critical factor as variation in feeding time and concentration can have a profound influence on enzyme activity. The systematic addition of inducer after regular intervals also resulted in pushing the exponential growth up to $30 \mathrm{~h}$ as against $24 \mathrm{~h}$ for single feeding thereby indicating the positive role of lactamide on the progression of cell growth. However, during multiple feedings of inducer the enzyme activity displayed a decreasing trend due to the inhibitory effect produced by the higher accumulation of the inducer in the production medium. Alternatively, the cells subjected to double feedings exhibited higher activity as compared to multiple feedings because the presence of reduced quantity of inducer helped in overcoming the inhibitory effect and simultaneously the enzymatic activity was also stimulated to a greater degree. Finally, 2.09 $\mathrm{U} / \mathrm{mgdcw}$ NHase activity was recorded with double feeding of $0.2 \%(\mathrm{w} / \mathrm{v})$ lactamide. Hence it may be safely concluded that a two-fold increase in enzyme activity became possible due to the implementation of a double-nourishment strategy whereby the inducer concentration was kept constant for both the feedings. In all the experiments the cells were harvested after $48 \mathrm{~h}$

Table 1 Effect of lactamide (inducer) on the NHase activity of $R$. pyridinovorans NIT-36 during single feeding of the inducer. The inducer was varied from $0.1 \%$ 
to $1.0 \% \mathrm{w} / \mathrm{v}$ and $0.2 \% \mathrm{w} / \mathrm{v}$ stimulated the enzyme activity to the highest degree whereas higher concentrations had an inhibitory effect on enzyme activity

\begin{tabular}{lcc}
\hline $\begin{array}{c}\text { Lactamide } \\
(\mathbf{\%} \text { w/v) }\end{array}$ & $\begin{array}{c}\text { Growth } \\
(\mathbf{m g ~ d c w} / \mathbf{m l})\end{array}$ & $\begin{array}{c}\text { Specific NHase activity } \\
(\mathbf{U} / \mathbf{m g ~ d c w})\end{array}$ \\
\hline 0.1 & 10 & 0.78 \\
\hline $\mathbf{0 . 2}$ & $\mathbf{1 0 . 7}$ & $\mathbf{1 . 2}$ \\
\hline 0.3 & 11 & 0.9 \\
\hline 0.4 & 10.5 & 0.6 \\
\hline 0.5 & 10.9 & 0.68 \\
\hline 0.6 & 11 & 0.63 \\
\hline 0.7 & 10.3 & 0.5 \\
\hline 0.8 & 10.2 & 0.54 \\
\hline 0.9 & 11 & 0.4 \\
\hline 1.0 & 10.6 & 0.5 \\
\hline
\end{tabular}

Table 2 Inducer (lactamide) feeding for hyperinduction of NHase for lactamide synthesis. The time interval, concentration of inducer and number of feedings were varied to regulate the induction mechanism and understand its effect on the growth and activity profile of $R$. pyridinivorans NIT-36. A comparative assessment of single feeding, double feeding and multiple feeding is presented in this table

\begin{tabular}{|c|c|c|c|}
\hline Experiment & $\begin{array}{c}\text { Lactamide } \\
\text { feeding }(w / v)\end{array}$ & $\begin{array}{c}\text { Growth } \\
(\mathrm{mg} \text { dcw/ml })\end{array}$ & $\begin{array}{c}\text { Nhase activity } \\
\text { U/mg dcw }\end{array}$ \\
\hline Control 1 & - & 12.0 & 0.001 \\
\hline Control 2 & $0 \mathrm{~h}: 0.2 \%$ & 11.0 & 0.34 \\
\hline Set 1 & $\begin{array}{l}0 \mathrm{~h}: 0.2 \% \\
12 \mathrm{~h}: 0.4 \% \\
24 \mathrm{~h}: 0.6 \% \\
36 \mathrm{~h}: 1.0 \%\end{array}$ & 15.0 & 0.8 \\
\hline Set 2 & $\begin{array}{l}0 \mathrm{~h}: 1.0 \% \\
12 \mathrm{~h}: 0.8 \% \\
24 \mathrm{~h}: 0.6 \% \\
36 \mathrm{~h}: 0.2 \%\end{array}$ & 13.0 & 0.7 \\
\hline Set 3 & $\begin{array}{l}0 \mathrm{~h}: 0.2 \% \\
24 \mathrm{~h}: 1.4 \%\end{array}$ & 11.0 & 1.2 \\
\hline Set 4 & $\begin{array}{ll:}0 \mathrm{~h}: & : 0.2 \% \\
24 \mathrm{~h}: & 0.2 \% \\
\end{array}$ & 10.5 & 2.09 \\
\hline
\end{tabular}

Statistical optimization of reaction conditions for lactamide synthesis using whole cells of $R$. pyridinivorans NIT-36

The induced cells of $R$. pyridinivorans NIT-36 were subjected to optimization of critical reaction parameters which included $\mathrm{pH}$ of the buffer system, temperature cell volume and substrate concentration. A realistic model was designed with the help of RSM to study the values of response variable (production of NHase) and 3D response surface plots were generated (Figure 2). We were able to study the effect of multiple variables simultaneously and interactive effect was studied. This approach also ensures that with less number of experiments, statistical analysis is also done.

The actual and predictive values for response and the analysis of variance for the quadratic equation are given in Table 3 and Table 4 respectively. The Model Fvalue of 16.42 implies the model is significant. (Table 4). The independent variables used for this study were $\mathrm{pH}$, substrate concentration, temperature and cell volume) at three levels $(-1,0,+1)$. Table 3 represents the response for the 21 trial runs, where maximum NHase activity observed in the run 2 i.e. $3.49 \mathrm{U} / \mathrm{mg}$ $\mathrm{dcw}$, whereas the minimum $(0.9 \mathrm{U} / \mathrm{mg} \mathrm{dcw})$ observed in the run 15 . The lack of fit F-value was 4.46 and the corresponding P-value 0.0959 represent the nonsignificant Lack of fit. The corresponding analysis of variance (ANOVA) of the quadratic model along with the regression coefficient $\left(\mathrm{R}^{2}\right)$, adjusted $\mathrm{R}^{2}$ and the predicted $\mathrm{R}^{2}$ are given in Table 4 and 5 . The significantly high value of $\mathrm{R}^{2}$ $(0.97 \%)$ shows the fitness of the model. According to the quadratic model, the optimum levels of four different variables are $\mathrm{pH}-7$, temperature $45^{\circ} \mathrm{C}$, substrate concentration $15 \mathrm{mM}$, cell volume-100 $\mu \mathrm{l}$ found in the trial run 2 with high response $(3.49 \mathrm{U} / \mathrm{mg} \mathrm{dcw}$ ) among all the experiments. The results were confirmed by HPLC in which only lactamide synthesis was observed and presence of lactic acid was not detected. Most of the optimization work previously attempted for NHase mediated amide synthesis did not include a comprehensive statistical approach. The application of RSM for the NHase mediated lactamide synthesis is a rapid approach in identifying not only the critical factors but also their individual and interactive effects. Hyper induction coupled with statistical optimization caused a three-fold elevation in enzyme activity from $1.2 \mathrm{U} / \mathrm{mg}$ dew to $3.49 \mathrm{U} / \mathrm{mg}$ dcw.

Table 3 Actual and Predicted responses of RSM experiments of reaction conditions for NHase production by $R$. pyridinivorans NIT-36. The highes activity was recorded in Run 2 with substrate concentration of $15 \mathrm{mM}$, cell volume $100 \mu \mathrm{l}, \mathrm{pH} 7.0$ and temperature of $45^{\circ} \mathrm{C}$

\begin{tabular}{|c|c|c|c|c|c|c|}
\hline $\begin{array}{l}\text { Run } \\
\text { (activity) }\end{array}$ & $\begin{array}{l}\text { Substrate } \\
\quad(\mathbf{m M})\end{array}$ & pH & $\begin{array}{l}\text { Cell } \\
\text { Vol. }\end{array}$ & Temperature & $\begin{array}{l}\text { NHase } \\
\text { activity } \\
\text { (actual) }\end{array}$ & $\begin{array}{c}\text { NHase } \\
\text { activity } \\
\text { (predicted) }\end{array}$ \\
\hline 1 & 10.0 & $\begin{array}{l}7.0 \\
\end{array}$ & 100.0 & 45.0 & 2.9 & $\mathbf{3 . 0 3 5}$ \\
\hline 2 & 15.0 & 7.0 & 100.0 & 45.0 & 3.49 & 3.111 \\
\hline 3 & 10.0 & 8.0 & 150.0 & \begin{tabular}{|l}
50.0 \\
\end{tabular} & 1.6 & 1.589 \\
\hline 4 & 15.0 & 8.0 & 100.0 & 45.0 & 2.4 & 2.535 \\
\hline 5 & 20.0 & 7.0 & 100.0 & 45.0 & 3.4 & $\mathbf{3 . 5 3 5}$ \\
\hline 6 & 20.0 & 8.0 & 150.0 & 40.0 & 1.6 & 1.589 \\
\hline 7 & 10.0 & 6.0 & 150.0 & 40.0 & 1.5 & 1.489 \\
\hline 8 & 20.0 & 8.0 & 50.0 & 40.0 & 1.4 & 1.343 \\
\hline 9 & 15.0 & 6.0 & 100.0 & 45.0 & 2.6 & 2.735 \\
\hline 10 & 15.0 & 7.0 & 100.0 & 45.0 & 3.1 & 3.111 \\
\hline 11 & 15.0 & 7.0 & 100.0 & 40.0 & 1.8 & 1.935 \\
\hline 12 & 15.0 & 7.0 & 100.0 & 45.0 & 3.2 & 3.111 \\
\hline 13 & 15.0 & 7.0 & 100.0 & 45.0 & 3.45 & 3.111 \\
\hline 14 & 15.0 & 7.0 & 150.0 & 45.0 & 3.25 & 3.292 \\
\hline 15 & 20.0 & 6.0 & 50.0 & 50.0 & 0.9 & $\mathbf{0 . 8 4 3}$ \\
\hline 16 & 15.0 & 7.0 & 50.0 & 45.0 & 2.7 & 2.927 \\
\hline 17 & 15.0 & $\mathbf{7 . 0}$ & 100.0 & $\mathbf{5 0 . 0}$ & 1.1 & 1.23 \\
\hline 18 & 15.0 & $\mathbf{7 . 0}$ & 100.0 & 45.0 & 3.12 & 3.111 \\
\hline 19 & 10.0 & 6.0 & 50.0 & 40.0 & 1.2 & 1.143 \\
\hline 20 & 20.0 & 6.0 & 150.0 & 50.0 & 1.2 & 1.189 \\
\hline 21 & 10.0 & 8.0 & 50.0 & 50.0 & 1.123 & 1.066 \\
\hline
\end{tabular}

Table 4 Analysis of variance (ANOVA) for quadratic model of reactions conditions for the production of lactamide. The statistical analysis, lack of fit value and $\mathrm{F}$ values indicate the data is statistically relevant.

\begin{tabular}{lclcll}
\hline Source & $\begin{array}{c}\text { Sum of } \\
\text { Squares }\end{array}$ & df & $\begin{array}{c}\text { Mean } \\
\text { Square }\end{array}$ & $\begin{array}{l}\text { F } \\
\text { Value }\end{array}$ & $\begin{array}{l}\text { p-value } \\
\text { Prob > F }\end{array}$ \\
\hline Model & 16.96 & 14 & 1.21 & 16.42 & $\begin{array}{l}0.0012 \\
\text { significant }\end{array}$ \\
\hline A-substrate & 0.13 & 1 & 0.13 & 1.69 & 0.2408 \\
\hline B-Ph & 0.020 & 1 & 0.020 & 0.27 & 0.6213 \\
\hline $\begin{array}{l}\text { C-cell } \\
\text { volume }\end{array}$ & 0.33 & 1 & 0.33 & 4.52 & 0.0775 \\
\hline $\begin{array}{l}\text { D- } \\
\text { temperature }\end{array}$ & 0.25 & 1 & 0.25 & 3.32 & 0.1183 \\
\hline AB & 0.092 & 1 & 0.092 & 1.25 & 0.3058 \\
\hline AC & $9.591 \mathrm{E}-003$ & 1 & $9.591 \mathrm{E}-003$ & 0.13 & 0.7308 \\
\hline AD & 0.074 & 1 & 0.074 & 1.01 & 0.3546 \\
\hline BC & $7.411 \mathrm{E}-004$ & 1 & $7.411 \mathrm{E}-004$ & 0.010 & 0.9234 \\
\hline $\mathrm{BD}$ & 0.13 & 1 & 0.13 & 1.83 & 0.2250 \\
\hline CD & $9.591 \mathrm{E}-003$ & 1 & $9.591 \mathrm{E}-003$ & 0.13 & 0.7308 \\
\hline $\mathrm{A}^{2}$ & 0.077 & 1 & 0.077 & 1.05 & 0.3454 \\
\hline $\mathrm{B}^{2}$ & 0.58 & 1 & 0.58 & 7.84 & 0.0312 \\
\hline $\mathrm{C}^{2}$ & $2.284 \mathrm{E}-006$ & 1 & $2.284 \mathrm{E}-006$ & $3.095 \mathrm{E}-$ & 0.9957 \\
\hline $\mathrm{D}^{2}$ & 5.94 & 1 & 5.94 & 80.57 & 0.0001 \\
\hline Residual & 0.44 & 6 & 0.074 & & \\
\hline Lack of Fit & 0.31 & 2 & 0.15 & 4.46 & 0.0959 not \\
\hline Pure Error & 0.14 & 4 & 0.034 & & \\
\hline Cor Total & 17.40 & 20 & & & \\
\hline R-Squared & 0.9746 & & & & \\
\hline & & & & & \\
\hline
\end{tabular}

Table 5 Standard deviation and R-square values for optimization. The coefficient of determination $\left(\mathrm{R}^{2}\right)$ for nitrile hydratase activity of the enzyme as a function of the independent variables was found to be $97 \%$, which showed that the model correlated well with measured data and was statistically significant

\begin{tabular}{llll}
\hline Std. Dev. & $\mathbf{0 . 2 7}$ & R-Squared & 0.9746 \\
\hline Mean & 2.24 & Adj R-Squared & $\mathbf{0 . 9 1 5 2}$ \\
\hline C.V.\% & 12.13 & Pred R-Squared & -1.4835 \\
\hline PRESS & 43.22 & Adeq Precision & 11.723 \\
\hline
\end{tabular}

Synthesis of lactamide at 1-L scale in a fed-batch reaction using whole cells of $R$. pyridinivorans NIT-36 
Prior to carrying out the fed-batch reaction the optimum enzyme-substrate ratio was evaluated for lactamide synthesis within a given time span. A complete conversion of $15 \mathrm{mM}, 20 \mathrm{mM}, 25 \mathrm{mM}$ and $30 \mathrm{mM}$ was achieved using 2, 4, 6 and $8 \mathrm{mg}$ resting cells $(\mathrm{dcw}) / \mathrm{ml}$. The time taken for these conversions were 30 min for $15 \mathrm{mM}$ substrate, $60 \mathrm{~min}$ for $20 \mathrm{mM}$ substrate, 90 min for $20 \mathrm{mM}$ substrate and $100 \mathrm{~min}$ for $30 \mathrm{mM}$ substrate respectively (Table 6).

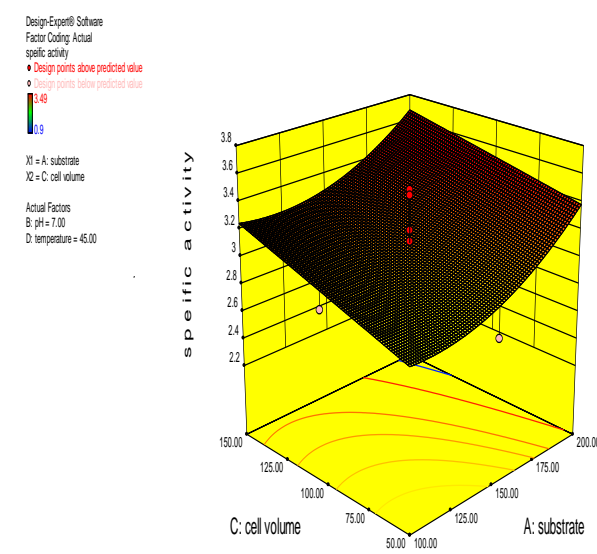

(a)

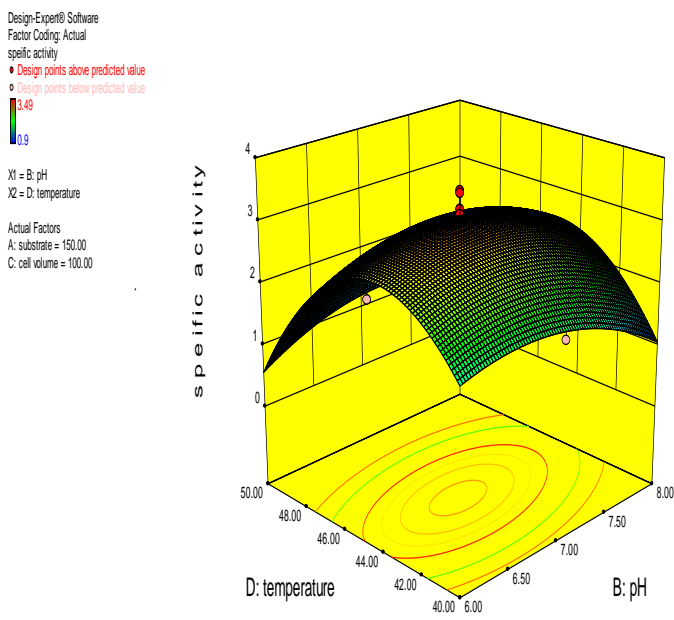

(c)
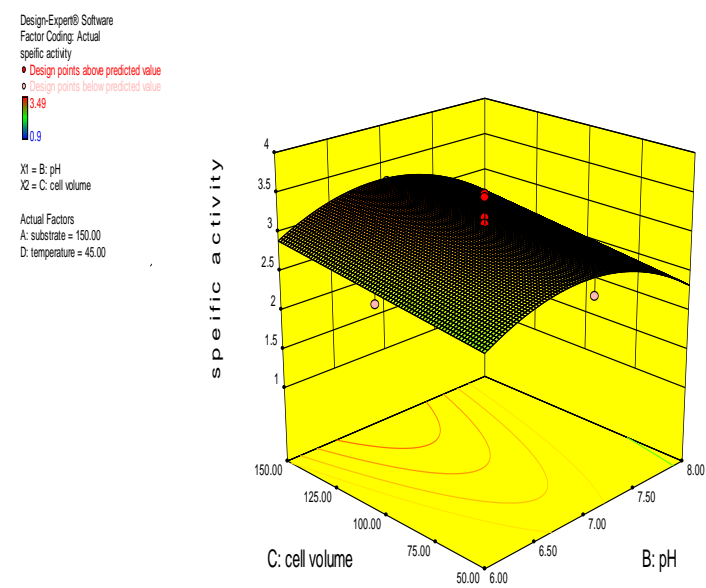

(b)
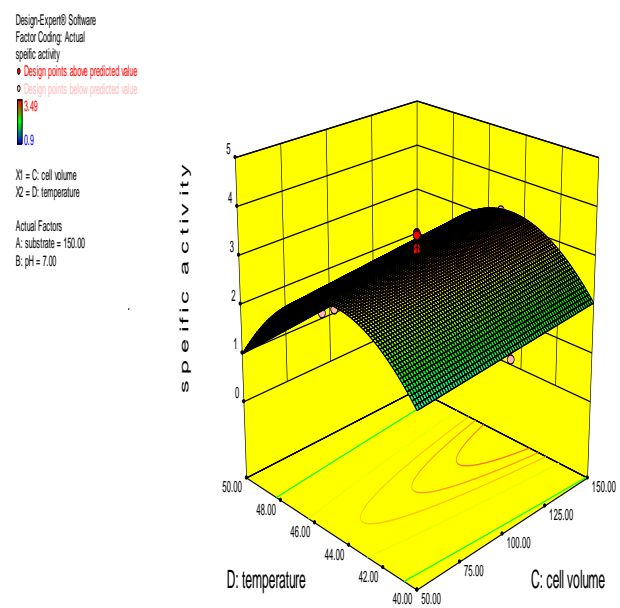

(d)

Figure 2 The 3D response plots representing the result of the RSM experiments on the production of lactamide by NHase. a) Showing the interaction between substrate and cell volume, b) $\mathrm{pH}$ and cell volume, c) $\mathrm{pH}$ and temperature and d) interaction between cell volume and temperature

Table 6 Optimization of substrate (Lactonitrile) and resting cells concentration of $R$. pyridinivorans NIT-36 for lactamide synthesis at $45^{\circ} \mathrm{C}$. The optimum ratio of enzyme and substrate was estimated for complete conversion of substrate to product which facilitated further scale up at $1 \mathrm{~L}$ scale

\begin{tabular}{lccc}
$\begin{array}{l}\text { Substrate } \\
\text { Lactonitrile } \\
(\mathrm{mM})\end{array}$ & $\begin{array}{c}\text { Resting cells of } R . \\
\text { pyridinivorans NIT- } \\
36(\mathrm{mg} / \mathrm{ml})\end{array}$ & $\begin{array}{c}\text { Time of } \\
\text { conversion }(\mathrm{min})\end{array}$ & \% conversion \\
\hline $\mathbf{1 5}$ & $\mathbf{2}$ & $\mathbf{3 0}$ & $\mathbf{1 0 0}$ \\
\hline $\mathbf{2 0}$ & $\mathbf{4}$ & $\mathbf{6 0}$ & $\mathbf{1 0 0}$ \\
\hline $\mathbf{2 5}$ & $\mathbf{6}$ & $\mathbf{9 0}$ & $\mathbf{1 0 0}$ \\
\hline $\mathbf{3 0}$ & $\mathbf{8}$ & $\mathbf{1 0 0}$ & $\mathbf{1 0 0}$ \\
\hline
\end{tabular}

Since minimum time of 30 minutes was achieved for complete conversion therefore a fed-batch reaction was designed at $1 \mathrm{~L}$ scale wherein $15 \mathrm{mM}$ substrate was fed into the reactor after regular intervals of $30 \mathrm{~min}$ each using least amount of biomass $(2 \mathrm{mg} / \mathrm{ml})$. The selection of $15 \mathrm{mM}$ substrate concentration also ensured less accumulation of substrate in the reaction vessel and hence enzyme repression was avoided during the later stages of feeding (Figure 3).

A total of 24 feedings were provided over a period of $12 \mathrm{~h}$ and product was allowed to accumulate in the reaction vessel. Finally, at the end of fed-batch reaction $35 \mathrm{~g} / \mathrm{L}$ and $14.5 \mathrm{~g} / \mathrm{gm} \mathrm{dcw} / \mathrm{h}$ of volumetric productivity and catalytic productivity respectively were obtained.

\section{DISCUSSION}

Nitrile hydratases have the ability to synthesize various amide compounds which find extensive use in chemical, agricultural and pharmaceutical industries. The conventional chemical synthesis of these amides is usually accomplished by employing harsh conditions which include usage of extreme $\mathrm{pH}$, temperature and pressure conditions and are usually accompanied with the generation of undesired by-products and toxic wastes. Conversely, NHase mediated biotransformation helps in dodging these pitfalls and better yield is attained under ambient conditions. NHase enzyme is inducible in nature and various nitrile and amide compounds serve as its activators. Thus, NHases along with amidases and nitrilases serve as potent enzymes for bioremediation of toxic nitrile compounds (He et al., 2010). 


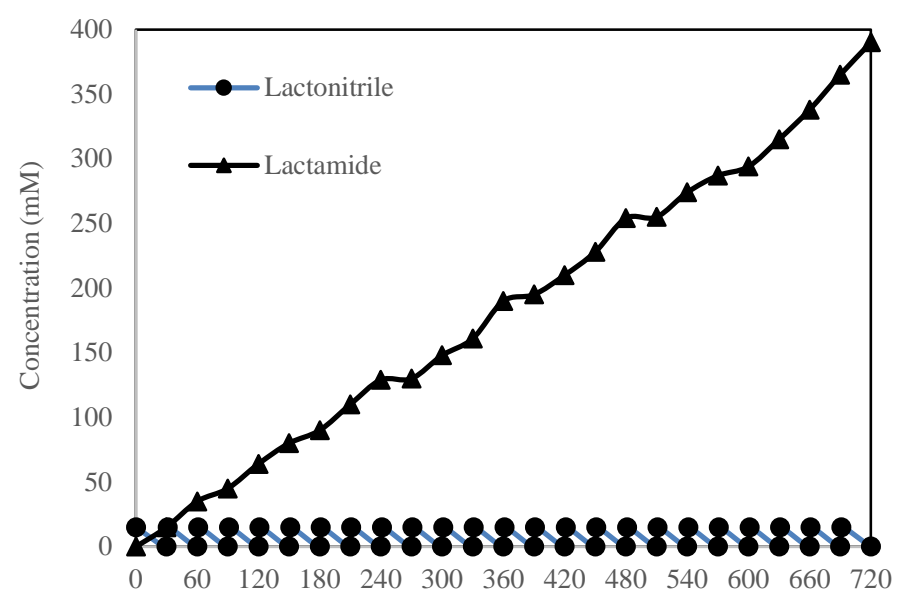

Time (min)

Figure 3 Formation of Lactamide in $1 \mathrm{~L}$ fed batch with 24 feedings of substrate $(15 \mathrm{mM})$ at an interval of $30 \mathrm{~min}$. The product was accumulated in the reaction vessel and a final output of $35 \mathrm{~g} / \mathrm{L}$ of purified lactamide

NHases are metalloenzymes which are of two broad types, namely Co-NHase (cobalt containing) and Fe-NHase (iron containing). These metals actively interact with the amino acids present in the catalytic center and facilitate enzymesubstrate interaction. The synthesis of NHase enzyme usually occurs during the early exponential phase to stationary phase. However, peak enzyme production cycle various in different organisms. The time interval for maximum enzyme production is $48 \mathrm{~h}$ in Rhodococcus sp. SHZ-1 (Wang et al. 2007), $34 \mathrm{~h}$ for Bacillus RAPe 8 strain (Ramakrishna and Desai, 1993), $45 \mathrm{~h}$ for Brevibacterium R312 strain (Tauber et al. 2000) and $72 \mathrm{~h}$ for Rhodococcus ruber (Zhang et al. 2009).

Conversion of lactonitrile to lactamide has attempted previously by employing chemical methods. This paper highlights the development of a fed-batch method for enzymatic bioconversion of lactonitrile to lactamide using NHase enzyme NHases have been reported for synthesis of various amides and amide-derivatives like butyramide (Raj et al. 2007), nicotinamide (Pratush et al. 2010; Pratush et al. 2011; Pratush et al. 2012; Pratush et al. 2013; Pratush et al. 2017), 5 cyanovaleramide (Hann et al. 1999), acrylamide (Nagasawa et al. 1993; Singh et al. 2017), pyrazinamide (Jin et al. 2010) and 2-amino-2,3 dimethylbutyramide (Lin et al. 2011). On the other hand, lactamide is normally synthesized by chemical methods. A number of such methods have been reported till date (Kanyon et al. 1949; Tanaka et al. 1998; Krieken, 2013; Bell and Tovey, 2015), but these techniques suffer from certain inherent drawbacks like use of expensive catalysts (prepared at temperatures around $100^{\circ} \mathrm{C}$ ). The additional shortcomings include engagement of high reaction temperatures in excess of $200{ }^{\circ} \mathrm{C}$ and incorporation of volatile organic solvents and toxic pesticides like cyproconazole during product development (Sugano et al. 2000; Bell and Tovey, 2007). These methods include hydrating lactonitrile in the presence of a catalyst mainly comprising of manganese oxide and a nitrogencontaining compound such as ammonia or diethylamine (Tanaka et al. 1998) The manganese oxide is prepared at around $100^{\circ} \mathrm{C}$ along with the usage of very harsh chemical reactions. These chemical processes cause the downstream processing to be very tedious and expensive and also confer low yield of the fina product. These limitations can be suitably overcome by adopting an enzyme mediated approach as is indicated by the use of NHase enzyme of $R$ pyridinivorans NIT-36 wherein lactonitrile biotransformation was made achievable at moderate reaction conditions.

The reactions catalyzed by the Nhases are generally carried out at $\mathrm{pH} 7.0$ (Payne et al., 1997, Nagasawa et al., 1993, Lee et al., 1993, Nagasawa et al., 1987), pH 6.5 (Tauber et al., 2000) and pH 8.5 (Sankhian et al., 2003). Although a number of amides are known to stimulate amidase activity in $R$. pyridinivorans NIT-36 (Kumari et al. 2016) but in this particular biotransformation an exception was recorded wherein selective activation of NHase was achieved accompanied with non-initiation of amidase enzyme thus demonstrating that inducers may share the same chemical grouping nonetheless dissimilarities in their structure and configurations have a varying effect on enzyme activity which is eventually responsible for the selective affinity of lactamide towards NHase as opposed to amidase enzyme. In the previous literature, various strains of Rhodococcus have been described where NHase and amidase are simultaneously activated and both amides and acids are produced from their corresponding nitriles. To overcome this limitation investigators have carried out reactions at low temperatures not exceeding $10^{\circ} \mathrm{C}$ to prevent activation of amidase (Nagasawa et al. 1993; Raj et al. 2007). Precigou et al. (2004) utilized $R$. pyridinivorans MW3 strain for acrylamide production and Kohyama et al. (2006) employed $R$. pyridinivornas S85-2 strain for acetonitrile degradation. Earlier, Maksimov et al. (2003) have utilized lactamide as an inducer for stimulating NHase activity in Rhodococcus sp. gt-1, however, the induced cells were eventually used for acrylamide production. In this given instance, the strain of $R$. pyridinivorans NIT-36 was selectively induced for NHase production followed by standardization of process parameters and eventually an efficient fed-batch reaction was designed for lactonitrile biotransformation. The performance of NHase of $R$. pyridinivorans NIT-36 for the synthesis of this important commodity chemical can further be enhanced by employing recombinant methods and this research can provide a framework for future advancements in enzyme immobilization as well as enzyme engineering.

\section{CONCLUSION}

This research was envisioned to comprehensively realize the catalytic potential of NHase enzyme system of $R$. pyridinivorans NIT-36 for lactamide synthesis. The selective induction approach coupled with statistical optimization significantly enhanced the catalytic potential of NHase enzyme and lactonitrile was efficiently converted to lactamide under ambient conditions without the intervention of acid byproducts.

Acknowledgement: Authors are highly thankful to Honorable Vice Chancellor, Prof. P. K. Khosla for providing necessary facilities to carry out this research work. This work was supported by the Science and Engineering Research Board (SERB), Department of Science and Technology, Government of India (Grant No.: SB/YS/LS-19/2013).

\section{REFERENCES}

Bell GA, Tovey ID (2007) Process for producing lactamide compounds, new lactamide compounds and Formulations containing lactamide compounds. WO 2007/107745, 27 September, 2007

Bell GA, Tovey ID (2015) Process for producing lactamide compounds, new lactamide compounds and formulations containing lactamide compounds European Patent EP2001288 B1, 24 June 2015

He YC, Xu JH, Su JH, Zhou L (2010) Bioproduction of Glycolic Acid from Glycolonitrile with a New Bacterial Isolate of Alcaligenes sp. ECU0401. Appl Biochem Biotechnol 160:1428-1440. https://doi.org/10.1007/s12010-009-8607-

Hann EC, Eisenberg A, Fager SK, Perkins NE, Gallagher FG, Cooper SM (1999) 5-Cyanovaleramide production using immobilized Pseudomonas chlororaphis B23. Bioorg Med Chem 7:2239-2245. https://doi.org/10.1016/S09680896(99)00157-1

Jin LQ, Liu ZQ, Zheng YG, Shen YC (2010) Identification and characterization of Serratia marcescens ZJB-09104, a nitrile converting bacterium. World J Microbiol Biotechnol 26: 817-823. https://doi.org/10.1007/s11274-009-0238-5 Jyoti, Bhatia K, Chauhan K, Attri C, Seth A (2017) Improving stability and reusability of Rhodococcus pyridinivorans NIT-36 nitrilase by whole cell immobilization using chitosan. Int $\mathrm{J}$ Biol Macromol 103: 8-15. https://doi.org/10.1016/j.ijbiomac.2017.05.012

Kanyon WO, Campen JHV (1949) N-Alkenyl lactamides. United States Paten US 2,490,756, 6 Dec 1949

Kohyama E, Yoshimura A, Aoshima D, Yoshida T, Kawamoto H, Nagasawa T (2006) Convenient treatment of acetonitrile-containing wastes using the tandem combination of nitrile hydratase and amidase-producing microorganisms. Appl Microbiol Biotechnol 72:600-606. https://doi.org/10.1007/s00253-005-0298-X

Krieken JV (2013) Process for manufacturing N, N-dialkyllactamide. United States Patent US 8,440,860 B2, 14 May 2013

Kumari A, Singh P, Seth AC, Seth A (2016) Batch and Fed-Batch production of Acetohydroxamic acid using amidase of hyperinduced cells of Rhodococcus pyridinivorans NIT-36. Res J Chem Environ 20 (7):35-47.

Lee CY, Choi SK, Chang HN (1993) Bench-scale production of acrylamide using the resting cells of Brevibacterium sp. $\mathrm{CH} 2$ in a fed-batch reactor. Enz Microbiol Technol 15:979-984. https://doi.org/10.1016/0141-0229(93)90175-2

Lin ZJ, Zheng RC, Zheng YG, Shen YC (2011) Biosynthesis of 2-amino-2, 3 dimethylbutyramide by nitrile hydratase from a newly isolated cyanide-resistan strain of Rhodococcus qingshengii. Biotechnol Lett 33:1809-1813. https://doi.org/10.1007/s10529-011-0623-7

Maksimov AY, Kuznetsova MV, Ovechkina GV, Kozlov SV, Maksimova YG, Demakov VA, (2003) Effects of nitriles and amides on the growth and nitrile hydratase activity of the Rhodococcus sp. Strain gt1. Appl. Biochem. Microbiol. 39(1) 55-59. https://doi.org/10.1023/A:1021798010261

Nagasawa T, Yamada H (1987) Nitrile hydratase is a quinoprotein a possible new function of pyrroloquinoline quinone: Activation of $\mathrm{H}_{2} \mathrm{O}$ in an enzymatic hydration reaction. Biochem Biophys Res Commun 147:701-709. https://doi.org/10.1016/0006-291X(87)90987-9

Nagasawa T, Shimizu H, Yamada H (1993) The superiority of the thirdgeneration catalyst Rhodococcus rhodochrous $\mathrm{J} 1$ nitrile hydratase for industrial production of acrylamide. Appl Microbiol Biotechnol 40:189-195. https://doi.org/10.1007/BF00170364 
Payne MS, Wu S, Fallon RD, Tudor G, Stieglitz B. Turner IM (1997) A stereoselective cobalt containing nitrile hydratase. Biochem 36:5447-5454. https://doi.org/10.1021/bi962794t

Pratush A, Seth A, Bhalla T C (2011) Optimization of process parameters for conversion of 3-cyanopyridine to nicotinamide using resting cells of mutant 4D strain of Rhodococcus rhodochrous. PA-34. Int J Bioauto 15 (3): 151-158

Pratush A, Seth A, Bhalla T.C. (2017) Expression of nitrile hydratase gene of mutant 4D strain of Rhodococcus rhodochrous PA-34 in Pichia pastoris. Biocatal Biotransform 35(1):19-26. https://doi.org/10.1080/10242422.2016.1247831

Pratush A, Seth A, Bhalla TC (2012) Cloning, Sequencing, and Expression of Nitrile hydratase Gene of Mutant 4D Strain of Rhodococcus rhodochrous PA 34 in E. coli. Applied Biochem and Biotechnol 168: 465-486. https://doi.org/10.1007/s12010-012-9790-9

Pratush A, Seth A, Bhalla TC (2010) Generation of mutant of Rhodococcus rhodochrous PA-34 through chemical mutagenesis for hyper production of nitrile hydratase. Acta Microbiol Et Immunol Hungar 57(2): 135-146. https://doi.org/10.1556/AMicr.57.2010.2.6

Pratush A, Seth A, Bhalla TC (2013) Purification and characterisation of nitrile hydratase of mutant 4D Rhodococcus rhodochrous PA-34. 3 Biotech 3 (2): 165171. https://doi.org/10.1007/s13205-012-0081-5

Precigou S, Wieser M, Pommares P, Goulas P, Duran R (2004) Rhodococcus pyridinovorans MW3, a bacterium producing a nitrile hydratase. Biotechnol Lett 26:1379-1384 https://doi.org/10.1023/B:BILE.0000045636.47527.99

Raj J, Seth A, Prasad S, Bhalla TC (2007) Bioconversion of butyronitrile to butyramide using whole cells of Rhodococcus rhodochrous

PA-34. Appl Microbiol Biotechnol 74:535-539. https://doi.org/10.1007/s00253006-0693-y

Ramakrishna C, Desai JD (1993) Superiority of cobalt induced acrylonitrile hydratase of Arthrobacter sp. IPCB-3 for conversion of acrylonitrile to acrylamide. Biotechnol Lett 15: 267-270. https://doi.org/10.1007/BF00128317

Sankhian UD, Kumar H, Chand D, Kumar D, Bhalla TC (2003) Nitrile hydratase of Rhodococcus rhodochrous NHB-2: optimization of conditions for production of enzyme and conversion of acrylonitrile to acrylamide. Asian Journal of Microbiology, Biotechnology and Environmental Sciences 5:217-223

Singh P, Kumari A, Attri C, Seth A (2017) Enhanced production of NHase of alkali stable Rhodococcus pyridinivorans NIT 36 and its application in acrylamide production. Int J Biol Pharm Allied Sci 6(2): 278-299

Sugano Y, Abe T, Nakano R (2000) Process for preparing lactamide United States Patent 6,124,501, 26 September, 2000

Tanaka F, Morimoto T, Uchiyama T (1998) Process for preparing lactamide. United States Patent 5,756,842, 26 May 1998

Tauber MM, Cavaco-Paulo A, Robra K-H, Gubitz GM (2000) Nitrile hydratase and amidase from Rhodococcus rhodochrous hydrolyse acrylic fibers and granular polyacrylonitriles. Appl Environ Microbiol 66:1634-1638. https://doi.org/10.1128/aem.66.4.1634-1638.2000 Wang C, Zhang G, Xu X, Li C (2007) Inducing Expression and Reaction Characteristic of Nitrile Hydratase from Rhodococcus sp. SHZ-1. Chinese J Chem Engi 15(4):573-578 https://doi.org/10.1016/S1004-9541(07)60126-8

Zhang J, Wang M, Sun H, Li XD, Zhong LP (2009) Isolation and characterization of Rhodococcus ruber CGMCC3090 that hydrolyzes aliphatic, aromatic and heterocyclic nitriles. Afr J Biotechnol 8:5467-5486. https://doi.org/10.5897/AJB09.795 